\title{
PENGARUH KECERDASAN INTERPERSONAL DAN TASK COMMITMENT TERHADAP PRESTASI BELAJAR MATEMATIKA SISWA KELAS VIII SMP NEGERI 1 SUNGGUMINASA
}

\author{
Sitti Rahmah Tahir ${ }^{1 *}$ \\ Nur Rifqah Anisah ${ }^{2}$ \\ Rukli $^{3}$ \\ 1,2,3Prodi Pendidikan Matematika Universitas Muhammadiyah Makassar, Indonesia

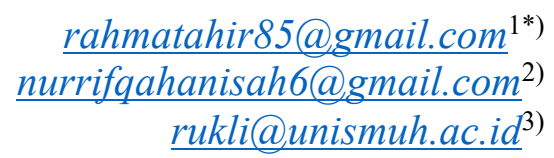

\begin{abstract}
Abstrak
Penelitian ini dilakukan untuk mengetahui: (1) seberapa besar gambaran kecerdasan interpersonal, task commitment dan prestasi belajar matematika siswa kelas VIII SMP Negeri 1 Sungguminasa. (2) pengaruh kecerdasan interpersonal dan task commitment terhadap prestasi belajar matematika siswa kelas VIII SMP Negeri 1 Sungguminasa. (3) pengaruh kecerdasan interpersonal terhadap prestasi belajar matematika siswa kelas VIII SMP Negeri 1 Sungguminasa. (4) pengaruh task commitment terhadap prestasi belajar matematika siswa kelas VIII SMP Negeri 1 Sungguminasa. Jenis penelitian ini adalah penelitian ex-post facto dengan sampel 67 siswa kelas VIII SMP Negeri 1 Sungguminasa tahun ajaran 2020/2021 dengan menggunakan teknik pengambilan sampel simple random samplingdenganmetode random (acak) melalui undian dari populasi seluruh kelas VIII SMP Negeri 1 Sungguminasa yang berjumlah 11 kelas. Teknik pengumpulan data menggunakan angket dan dokumentasi.Teknik analisis data menggunakan statistik deskriptif dan statistik inferensial. Hasil penelitian menunjukkan bahwa: (1) gambaran umum kecerdasan interpersonal dan task commitment siswa dalam kategori sangat baik dengan persentase sebesar $48 \%$ dan 33\%, sedangkan variabel prestasi belajar matematika siswa kelas VIII SMP Negeri 1 Sungguminasa berada pada kategori baik dengan persentase sebesar 39\%. (2) terdapat pengaruh kecerdasan interpersonal dan task commitment secara bersama-sama terhadap prestasi belajar matematika siswa kelas VIII SMP Negeri 1 Sungguminasa dengan taraf signifikansi $0,000<$ 0,05 dan nilai $F_{\text {hitung }}>F_{\text {tabel }}(468,325>3,14)$. (3) terdapat pengaruh kecerdasan interpersonal terhadap prestasi belajar matematika siswa kelas VIII SMP Negeri 1 Sungguminasa dengan nilai signifikansi $0,000<0,05$ dan nilai $t_{\text {hitung }}>t_{\text {tabel }}(5,497>1,9971)$. (4) terdapat pengaruhtask commitment terhadap prestasi belajar matematika siswa kelas VIII SMP Negeri 1 Sungguminasa dengan taraf signifikansi $0,000<0,05$ dan nilai $t_{\text {hitung }}>t_{\text {tabel }}(10,433>1,9971)$.
\end{abstract}

Kata kunci: Kecerdasan Interpersonal, Task Commitment, Prestasi Belajar Matematika

Published by:

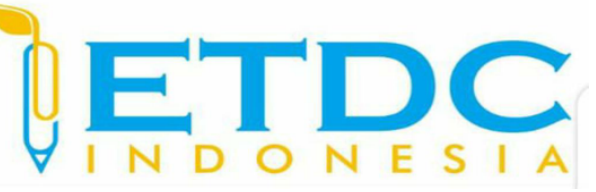

Copyright (C) 2021 The Author (s)

This article is licensed under CC BY 4.0 License

(cc) $\mathrm{BY}$ 


\section{PENGARUH KECERDASAN INTERPERSONAL DAN TASK COMMITMENT TERHADAP PRESTASI BELAJAR MATEMATIKA SISWA KELAS VIII SMP NEGERI 1 SUNGGUMINASA}

\section{Pendahuluan}

Pendidikan adalah upaya dalam mempersiapkan siswa untuk menjadi seseorang yang bermanfaat dan berkualitas.Pendidikan sebelumnya telah dirancang untuk mencapai suatu tujuan yang telah ditetapkan.Pendidikan memiliki tujuan dalam peningkatan kualitas SDM (Sumber Daya Manusia) yaitu salah satunya dengan menolong siswa dalam mengembangkan potensi yang dimiliki semaksimal mungkin.

Belajar menurut Aunurrahman (Hidayat, 2019:14) merupakan perubahan sebuah tingkah laku pribadi seseorang akibat adanya interaksi antarsesama ataupun interaksi dengan lingkungan. Slameto (2010:2) juga mengungkapkan bahwa belajar merupakan upaya yang dilakukan seseorang untuk memperoleh perubahan tingkah laku yang baru agar mendapatkan hasil pengalaman pada dirinya setelah terjadi interaksi dengan lingkungan. Perubahan tingkah laku yang dimaksudkan yaitu hasil dari proses belajar seseorang yang dilihat dari perubahan knowledge (pengetahuan), perubahan understanding (pemahaman), attitude (sikap), behavior (tingkah laku), kecakapan dan kebiasaan serta perubahan aspek lainnya dalam diri seseorang.

Belajar matematika sangat diperlukan agar siswa berpikir secara logis dan kritis serta memiliki kemampuan dalam menyelesaikan berbagai masalah dalam kehidupan seharihari.Suhendri (2011:32) mengemukakan bahwa matematika ialah ilmu yang mempelajari suatu angka (bilangan), bangun-bangun, konsep, prinsip, hubungan dan logika untuk menyelesaikan suatu permasalahan yang terdapat dalam kehidupan sehari-hari dengan menggunakan bahasa lambang atau biasa juga disebut dengan simbol.Siswa yang berhasil dalam pendidikan akan memperoleh nilai sebagai hasil belajar atau sering juga disebut dengan prestasi belajar. Menurut Sardiman (2014:46), definisi dari prestasi belajar ialah kemampuan yang dimiliki dari reaksi yang tercipta ketika berinteraksi dengan beberapa faktor yang sangat berpengaruh baik dari dalam individu itu sendiri maupun dari luar individu dalam pembelajaran.

Banyak hal yang dapat mempengaruhi prestasi belajar siswa salah satunya yaitu kecerdasan interpersonal.Kecerdasan interpersonal berdasarkan Lwin (2008:197) ialah kemampuan dalam memahami dan memperkirakan perasaan, suasana hati, serta keinginan orang lain dan dapat memberi respon dengan layak.Kemampuan yang dimilik seseorang dalam menanggapi dan memberi respon secara cermat dan teliti terhadap suasana hati, maksud, 
motivasi, perasaan, dan keinginan dari orang lain serta mampu bekerja sama dan bersosialisasi dengan orang-orang disekitarnya terkhusus dalam lingkungan sekolah menjadi unsur pokok suatu kecerdasan interpersonal. Siswa yang tinggi kecerdasan interpersonalnya, cenderung mudah memahami maksud dan perasaan orang lain, bekerja sama dengan orang lain serta dapat mengembangkan hubungan yang harmonis sehingga sangat mudah dalam bersosialisasi.Biasanya, siswa yang mempunyai kecerdasan interpersonal dilihat dari mereka yang bercita-cita menjadi ketua kelas dan pintar dalam mengkomunikasikan keinginannya kepada orang-orang sekitarnya.

Berdasarkan hasil observasi yang dilakukandi SMP Negeri 1 Sungguminasa, adapun permasalahan yang timbul, pertama yakni masih banyak siswa yang bersikap kurang bersosialisasi terhadap guru ataupun temannya sehingga ia mengalami kesulitan dalam menyampaikan apa yang diinginkan. Kedua, kurangnyaketerampilansiswa dalam menyelesaikan soal-soal matematika, hal tersebut terjadi karena tidak ada motivasi atau tekad yang kuat untuk berusaha dalam menciptakan hal-hal baru.Ketiga, masih banyak siswa yang kurang berpastisipasi bahkan lebih senang berdiam diri dalam kegiatan pembelajaran dikarenakan tidak ada kepercayaan dirinya. Kondisi tersebut sangat berbeda dengan kondisi yang semestinya terjadi pada saat proses pembelajaran matematika. Optimalnya, siswa diharapkan fokus ketika mendengarkan penjelasan dari guru, melakukan diskusi untuk menggali informasi penting dalam pembelajaran, bersikap sopan dan santun, serta aktif berpartisipasi dalam pembelajaran.

Keberhasilan siswa dalam pembelajaran tidak hanya ditinjau dari pengaruh yang timbul akibat aspek intelegensi atau kecerdasan yang dimiliki.Tetapi faktor task commitment juga menjadi faktor penunjang keberhasilan.Task commitment berarti komitmen pada tugas.Task commitment ialah suatu tekad atau ambisi seseorang, yang tidak mengedepankan dorongan dari luar dalam mencapai suatu prestasi yang ditunjukkan dari sikap tangguh, ulet, tidak mudah bosan, mandiri, menetapkan tujuan aspirasi yang realitas dengan resiko sedang, suka belajar dan mempunyai hasrat untuk meningkatkan diri dan berhasil dalam bidang akademis. Siswa yang berkomitmen pada tugas (task commitment) dapat dilihat dari sikap positif yang ditunjukkan terhadap tugas yang diberikan tentunya sebagai seorang pelajar. Siswa tidak akan menganggap tugas yang diberikan adalah beban, ia malah akan berusaha dengan keras, bertekad, ulet dan kontinu untuk memberikan hasil secara maksimal terhadap pekerjaan yang telah diberikan. Selain hal tersebut, tingginya task commitment siswa terlihat dari sikap siswa yang tidak gampang puas dengan pekerjaan yang apa adanya, ia memiliki keinginan yang tinggi dalam menyelesaikan tugas dengan cepat dan tepat serta memberikan hasil yang memuaskan. 
Berdasarkan uraian diatas, penulis ingin mengetahui seberapa besar pengaruh antara kecerdasan interpersonal dan task commitment secara bersama-sama terhadap prestasi belajar matematika, pengaruh antara kecerdasan interpersonal terhadap prestasi belajar matematika dan pengaruh antara task commitment terhadap prestasi belajar siswa. Oleh sebab itu, penulis tertarik ingin melakukan penelitian yang berjudul "PENGARUH KECERDASAN INTERPERSONAL DAN TASK COMMITMENT TERHADAP PRESTASI BELAJAR MATEMATIKA SISWA KELAS VIII SMP NEGERI 1 SUNGGUMINASA".

\section{Metode Penelitian}

Sesuai dengan permasalahan penelitian sebagaimana telah dirumuskan sebelumnya, penelitian ini termasuk dalam jenis penelitian ex-post facto. Ex post facto berarti sebuah fakta yang terjadi. Penelitian ini tidak memberikan perlakuan melainkan mengungkapkan hal yang terjadi secara alamiah dan sudah berlangsung yang mempunyai keterikatan antara variabel dependen dengan independen sehingga peneliti dapat melacak kembali jika dimungkinkan apa yang menjadi faktor penyebabnya.Penelitian ini terdiri dari tiga variabel yaitu dua variabel bebas yakni kecerdasan interpersonal $\left(\mathrm{X}_{1}\right)$ dan task commitment $\left(\mathrm{X}_{2}\right)$, dan satu variabel terikat yaitu prestasi belajar matematika $(Y)$.

Penelitian ini dilaksanakan di SMP Negeri 1 Sungguminasa tepatnya di kelas VIII. Populasi dalam penelitian ini adalah seluruh siswa kelas VIII SMP Negeri 1Sungguminasa yang terdiri dari 11 kelas yang berjumlah 400 siswa.Teknik pengambilan sampel yang digunakan ialah tekniksimple random samplingdengan metode acak (random) melalui undian sehingga diperoleh sampel penelitian sebanyak 2 kelas yakni kelas VIII C dan VIII D yang berjumlah 67 siswa.Adapaun teknik pengumpulan data menggunakan metode angket untuk data kecerdasan interpersonal dan task commitmentserta dokumentasi nilai rapor matematika semester ganjil tahun ajaran 2020/2021 kelas VIII SMP Negeri 1 Sungguminasa untuk data prestasi belajar matematika. Instrumen angket kecerdasan interpersonal dan task commitment menggunakan skala likert yang terdiri dari empat pilihan jawaban yakni: Sangat Setuju (SS), Setuju (S), Tidak Setuju (ST) dan Sangat Tidak Setuju (STS). Skor masing-masing untuk pernyataan positif diperoleh Sangat Setuju $(\mathrm{S})=4$, Setuju $(\mathrm{S})=3$, Tidak Setuju $(\mathrm{TS})=2$ dan Sangat Tidak Setuju $(\mathrm{STS})=1$ dan skor sebaliknya untuk pernyataan negatif.

Teknik analisis data yang digunakan adalah analisis statistik deskiptif dan statistik inferensial.Analisis statistik deskriptif digunakanuntuk mendeskripsikan suatu obyek penelitian secara sistematis dan akurat tanpa adanya manipulasi terhadap fakta yang ada. Untuk itu, diperlukan tabel distribusi frekuensi untuk melihat mean (rata-rata), median, range, nilai 
minimum, nilai maksimum dan persentase tiap variabel.Sedangkan analisis statistik inferensial.untuk menganalisis data prestasi belajar, kecerdasan interpersonal dan task commitment dengan menggunakan uji regresi linear berganda. Teknik analisis regresi digunakan untuk mengetahui pengaruh antar variabel dengan mengontrol variabel lain.

\section{Hasil dan Pembahasan}

\section{Hasil Analisis Statistik Deskriptif}

1. Variabel Kecerdasan Interpersonal

Tabel 1. Statistik Deskriptif Kecerdasan Interpersonal

\begin{tabular}{cc}
\hline Statistik & Kecerdasan Interpersonal \\
\hline Ukuran Sampel & 67 \\
Skor Ideal & 100 \\
Mean & 81 \\
Median & 80 \\
Range & 40 \\
Nilai Minimum & 55 \\
Nilai Maksimum & 95 \\
Jumlah Skor & 5415 \\
\hline
\end{tabular}

Tabel 2. Distribusi Frekuensi dan Persentase Skor Kecerdasan Interpersonal

\begin{tabular}{cccc}
\hline Interval Skor & Frekuensi & Persentase & Kategori \\
\hline $\mathrm{X}<65$ & 3 & $4 \%$ & Buruk \\
$65 \leq \mathrm{X}<75$ & 12 & $18 \%$ & Kurang Baik \\
$75 \leq \mathrm{X}<85$ & 20 & $30 \%$ & Baik \\
$\mathrm{X} \geq 85$ & 32 & $48 \%$ & Sangat Baik \\
\hline Total & 67 & $100 \%$ & \\
\hline
\end{tabular}

Berdasarkan Tabel 2, maka dapatdisimpulkan bahwa kecerdasan interpersonal termasuk dalam kategori sangat baik dengan persentase sebesar $48 \%$.

2. Variabel Task Commitment

Tabel 3. Statistik Deskriptif Task Commitment

\begin{tabular}{cc}
\hline Statistik & Task Commitment \\
\hline Ukuran Sampel & 67 \\
Skor Ideal & 100 \\
Mean & 82 \\
Median & 85 \\
Range & 30 \\
Nilai Minimum & 65 \\
Nilai Maksimum & 95 \\
Jumlah Skor & 5496 \\
\hline
\end{tabular}


Tabel 4. Distribusi Frekuensi dan Persentase Skor Task Commitment

\begin{tabular}{cccc}
\hline Interval Skor & Frekuensi & Persentase & Kategori \\
\hline $\mathrm{X}<73$ & 10 & $15 \%$ & Buruk \\
$73 \leq \mathrm{X}<80$ & 15 & $22 \%$ & Kurang Baik \\
$80 \leq \mathrm{X}<88$ & 20 & $30 \%$ & Baik \\
$\mathrm{X} \geq 88$ & 22 & $33 \%$ & Sangat Baik \\
\hline Total & 67 & $100 \%$ & \\
\hline
\end{tabular}

Berdasarkan Tabel 4, maka dapat disimpulkan bahwa task commitment termasuk dalam kategori sangat baik dengan persentase sebesar 33\%.

3. Variabel Prestasi Belajar Matematika

Tabel 5. Statistik Deskriptif Prestasi Belajar Matematika

\begin{tabular}{cc}
\hline Statistik & Prestasi Belajar Matematika \\
\hline Ukuran Sampel & 67 \\
Skor Ideal & 100 \\
Mean & 82 \\
Median & 83 \\
Range & 29 \\
Nilai Minimum & 65 \\
Nilai Maksimum & 94 \\
Jumlah Skor & 5474 \\
\hline
\end{tabular}

Tabel 6. Distribusi Frekuensi dan Persentase Skor Prestasi Belajar Matematika

\begin{tabular}{cccc}
\hline Interval Skor & Frekuensi & Persentase & Kategori \\
\hline $0<x \leq 79$ & 24 & $36 \%$ & Kurung \\
$79<x \leq 84$ & 11 & $16 \%$ & Cukup \\
$84<x \leq 92$ & 26 & $39 \%$ & Baik \\
$92<x \leq 100$ & 6 & $9 \%$ & Sangat Baik \\
\hline Total & 67 & $100 \%$ & \\
\hline
\end{tabular}

Berdasarkan Tabel 6, maka dapat disimpulkan bahwa prestasi belajar matematika termasuk dalam kategori baik dengan persentase sebesar $39 \%$.

\section{Hasil Analisis Statistik Inferensial}

1. Pengujian Prasyarat

a. Uji Normalitas

Tabel 7. Hasil Uji Normalitas One Sample Kolmogrov-Smirnov Test

\begin{tabular}{cccc}
\hline & $\begin{array}{c}\text { Kecerdasan } \\
\text { Interpersonal }\end{array}$ & $\begin{array}{c}\text { Task } \\
\text { Commitment }\end{array}$ & $\begin{array}{c}\text { Prestasi Belajar } \\
\text { Matematika }\end{array}$ \\
\hline$N$ & 67 & 67 & 67 \\
Kolmogrov-Smirnov $Z$ & 1,247 & 1,327 & 1,153 \\
Asymp. Sig. (2-tailed) & 0,089 & 0,059 & 0,140 \\
\hline
\end{tabular}

Dari hasil output normalitas data dengan menggunakan SPSS versi 16 pada Tabel

7 tersebut diperoleh nilai signifikan untuk variabel kecerdasan interpersonal $\left(\mathrm{X}_{1}\right)$ adalah 0,089 variabel task commitment $\left(\mathrm{X}_{2}\right)$ adalah 0,059 dan variabel prestasi belajar 
matematika (Y) adalah 0,140. Sehingga data tersebut dikatakan berdistribusi normal karena nilai signifikan masing-masing variabel lebih besar dari taraf signifikan $\alpha=0,05$. b. Uji Linearitas

Tabel 8. Hasil Uji Linearitas Y Dengan $\mathrm{X}_{1}$ Tabel ANOVA

\begin{tabular}{|c|c|c|c|c|c|c|}
\hline & & & & & $F$ & Sig. \\
\hline Prestasi & Belajar & Between & (Combined) & & 36,590 & 0,000 \\
\hline $\begin{array}{l}\text { Matematika } \\
\text { * Kecerdasan }\end{array}$ & & Groups & Linearity & & 290,137 & 0,000 \\
\hline Interpersonal & & & $\begin{array}{l}\text { Deviation } \\
\text { Linearity }\end{array}$ & from & 0,369 & 0,917 \\
\hline
\end{tabular}

Hasil pengujian liniearitas berdasarkan data yang terdapat pada Tabel 8 diatas diperoleh nilai signifikansi pada tabeldeviation from linearity sebesar 0,917. Karena nilai signifikansi yang diperoleh lebih besar dari taraf signifikan $\alpha=0,05$, maka dapat disimpulkan bahwa terdapat hubungan yang bersifat linear antara variabel prestasi belajar matematika dengan variabel kecerdasan interpersonal.

Tabel 9. Hasil Uji Linearitas $Y$ Dengan $X_{2}$ Tabel ANOVA

\begin{tabular}{|c|c|c|c|c|c|c|}
\hline & & & & & $F$ & Sig. \\
\hline \multirow{3}{*}{$\begin{array}{l}\text { Prestasi } \\
\text { Matematika } \\
\text { Commitment }\end{array}$} & Belajar & Between & (Combined) & & 35,293 & 0,000 \\
\hline & *Task & Groups & Linearity & & 649,996 & 0,000 \\
\hline & & & $\begin{array}{l}\text { Deviation } \\
\text { Linearity }\end{array}$ & from & 1,142 & 0,345 \\
\hline
\end{tabular}

Hasil pengujian liniearitas berdasarkan data yang terdapat pada Tabel 9 diatas diperoleh nilai signifikansi pada tabel deviation from linearity sebesar 0,345. Karena nilai signifikansi yang diperoleh lebih besar dari taraf signifikan $\alpha=0,05$, maka dapat disimpulkan bahwa terdapat hubungan yang bersifat linear antara variabel prestasi belajar matematika dengan variabel task commitment

c. Uji Multikolinieritas

Tabel 10. Hasil Uji Multikolinearitas Variabel Bebas

\begin{tabular}{clcc}
\multicolumn{3}{c}{ Coefficients $^{a}$} \\
\cline { 3 - 4 } & \multirow{2}{*}{ Model } & \multicolumn{2}{c}{ Collinearity Statistics } \\
\hline \multirow{nyy}{*}{1} & $\begin{array}{l}\text { (constant) } \\
\text { Kecerance }\end{array}$ & VIF \\
& Interpersonal & 0,254 & 3,934 \\
& Task Commitment & 0,254 & 3,934 \\
\hline
\end{tabular}


Pada Tabel 10 hasil analisis uji multikolinieritas yaitu tidak terjadi multikolinieritas antara masing-masing variabel bebas, karena nilai toleransi lebih besar dari 0,10 dan nilai VIF lebih kecil dari 10,00

2. Pengujian Hipotesis

a. Hasil uji-f

Tabel 11. Hasil Analisis Uji-f secara bersama-sama

\begin{tabular}{|c|c|c|c|c|c|}
\hline Model & $\begin{array}{l}\text { Sum of } \\
\text { Squares }\end{array}$ & $f$ & $\begin{array}{l}\text { Mean } \\
\text { Square }\end{array}$ & $F$ & Sig. \\
\hline Regression & 3785.380 & & 1892.690 & 468.325 & $000^{\circ}$ \\
\hline Residual & 258.650 & 4 & 4.041 & & \\
\hline Total & 4044.030 & 6 & & & \\
\hline
\end{tabular}

Dari hasil pengujian Tabel 11 tersebut dapat dijelaskan bahwa nilai $\mathrm{F}_{\text {hitung }}$ yaitu 468,325 dan nilai signifikansi bernilai 0,000. Adapun untuk menentukan $\mathrm{F}_{\text {tabel }}$ digunakan rumus $\quad \mathrm{F}_{\text {tabel }}=(k-1 ; n-k-1)=(3-1 ; 67-3-1)=(2 ; 65)=3,14$. Karena nilai $\mathrm{F}_{\text {hitung }}>\mathrm{F}_{\text {tabel }}(468.325>3,14)$ dan nilai signifikansi $0,000<0,05$ maka disimpulkan bahwa kecerdasan interpersonal dan task commitmentsecara bersama-sama memiliki pengaruh terhadap prestasi belajar matematika siswa kelas VIII SMP Negeri 1 Sungguminasa.

b. Hasil uji-t

Tabel 12. Hasil Analisis Uji-t Coefficients $^{a}$

\begin{tabular}{llcr}
\hline \multicolumn{1}{c}{ Model } & $T$ & Sig. \\
\hline 1 & (constant) & 3,379 & 0,001 \\
& Kecerdasan & 5,497 & 0,000 \\
& Interpersonal & 10,433 & 0,000 \\
\hline
\end{tabular}

Berdasarkan dari Tabel 12 dapat dijelaskan sebagai berikut: (1) diperoleh nilai $\mathrm{t}_{\text {hitung }}$ sebesar 5,497 dan nilai signifikansi bernilai 0,000 untuk variabel kecerdasan interpersonal. Adapun untuk menentukan $\mathrm{t}_{\text {tabel }}$ digunakan rumus: $\mathrm{t}_{\text {tabel }}=\left(\frac{\alpha}{2} ; n-k-\right.$ 1) $=\left(\frac{0,05}{2} ; 67-3-1\right)=(0,025 ; 65)=1,9971$. Karena nilai $t_{\text {hitung }}>t_{\text {tabel }}$ $(5,497>1,9971)$ dan nilai signifikansi $0,000<0,05$, maka disimpulkan bahwa kecerdasan interpersonal memiliki pengaruh terhadap prestasi belajar matematika siswa 
kelas VIII SMP Negeri 1 Sungguminasa. (2) diperoleh nilai $t_{\text {hitung }}$ sebesar 10,433 dan nilai signifikansi bernilai 0,000 untuk variabel task commitment. Adapun untuk menentukan $t_{\text {tabel }}$ digunakan rumus $: t_{\text {tabel }}=\left(\frac{\alpha}{2} ; n-k-1\right)=\left(\frac{0,05}{2} ; 67-3-1\right)=$ $(0,025 ; 65)=1,9971$. Karena nilai $t_{\text {hitung }}>\mathrm{t}_{\text {tabel }}(10,433>1,9971)$ dan nilai signifikansi $0,000<0,05$, maka dapat disimpulkan bahwa task commitment memiliki pengaruh terhadap prestasi belajar matematika siswa kelas VIII SMP Negeri 1 Sungguminasa.

\section{Pembahasan}

1. Gambaran Umum Tiap Variabel

a. Kecerdasan Interpersonal

Berdasarkan hasil penelitian yang telah dilakukan maka diperoleh bahwa nilai rata-rata skor kecerdasan interpersonal siswa adalah 81 . Nilai median sebesar 80 yang menunjukkan bahwa ada sekitar 50\% siswa yang memperoleh nilai paling rendah 80 atau paling tinggi 80. Nilai minimum dan maksimum yang diperoleh siswa masing-masing 55 dan 95.

Adapun secara umum skor variabel kecerdasan interpersonal termasuk dalam kategori sangat baik dari dari 67 siswa sebagai sampel dalam penelitian ini, dilihat bahwa terdapat 3 siswa (4\%) tergolong dalam kategori buruk, 12 siswa (18\%) tergolong dalam kategori kurang baik, 20 siswa (30\%) tergolong dalam kategori baik dan 32 siswa (48\%) tergolong dalam kategori sangat baik.

Hal ini sejalan dengan penelitian yang dilakukan oleh Rohman (2015) yang menyatakan bahwa keberhasilan dalam meningkatkan prestasi belajar yang baik dapat dilihat siswa yang memiliki kecerdasaan interpersonal yang baik dengan maksud siswa akan mampu bersosialisasi dan mampu menjalin hubungan baik sehingga tidak merasa malu atau canggung apabila hendak meminta bantuan kepada teman dalam belajar. Kecerdasan intrpersonal sangat penting karena pada dasarnya manusia itu makhluk sosial, manusia akan saling membutuhkan satu sama lain untuk kesejahteraan hidupnya. Hal ini mengisyaratkan seorang guru dalam pencapaian belajar yang optimal. Guru hendaknya memperhatikan tingkat kecerdasan interpersonal siswa dengan menyesuaikan model atau metode pembelajaran yang dapat memacu kecerdasan interpersonal siswa menjadi lebih baik. 


\section{b. Task Commitment}

Berdasarkan hasil penelitian yang telah dilakukan maka diperoleh bahwa nilai rata-rata skor task commitment siswa adalah 82. Nilai median sebesar 85 yang menunjukkan bahwa ada sekitar 50\% siswa yang memperoleh nilai paling rendah 85 atau paling tinggi 85. Nilai minimum dan maksimum yang diperoleh siswa masing-masing 65 dan 95.

Adapun secara umum skor variabel task commitmenttermasuk dalam kategori sangat baik dari dari 67 siswa sebagai sampel dalam penelitian ini, dilihat bahwa terdapat 10 siswa (15\%) tergolong dalam kategori buruk, 15 siswa (22\%) tergolong dalam kategori kurang baik, 20 siswa (30\%) tergolong dalam kategori baik dan 22 siswa (33\%) tergolong dalam kategori sangat baik.

Hal ini sejalan dengan penelitian yang dilakukan oleh Pianyta (2016) yang menyatakan bahwa task commitment sangat berpengaruh signifikan terhadap prestasi belajar.Task commitment siswa menjadikan suatu motivasi untuk dapat menstimulus semangat dalam belajar khususnya pada materi pembelajaran matematika, sehingga secara langsung akan dapat meningkatkan prestasi belajar matematika menjadi lebih baik. Oleh karena itu, task commitment siswa harus dibangun secara kontinu dengan progres yang jauh lebih baik lagi untuk periode berikutnya.

c. Prestasi Belajar Matematika

Berdasarkan hasil penelitian yang telah dilakukan maka diperoleh bahwa nilai rata-rata skor prestasi belajar matematika siswa adalah 82 . Nilai median sebesar 83yang menunjukkan bahwa ada sekitar 50\% siswa yang memperoleh nilai paling rendah 83 atau paling tinggi 83. Nilai minimum dan maksimum yang diperoleh siswa masing-masing 65 dan 94.

Adapun secara umum skor variabel prestasi belajar matematika termasuk dalam kategori baik dari dari 67 siswa sebagai sampel dalam penelitian ini, dilihat bahwa terdapat 24 siswa (36\%) tergolong dalam kategori kurang, 11 siswa (16\%) tergolong dalam kategori cukup, 26 siswa (39\%) tergolong dalam kategori baik dan 6 siswa (9\%) tergolong dalam kategori sangat baik.

2. Pengaruh Kecerdasan Interpersonal dan Task Commitment terhadap Prestasi Belajar Matematika $\left(\mathrm{X}_{1}, \mathrm{X}_{2}-\mathrm{Y}\right)$

Hasil penelitian yang diperoleh dari uji regresi linear berganda yakni terdapat pengaruh kecerdasan interpersonal dan task commitment terhadap prestasi belajar matematika siswa kelas 
VIII SMP Negeri 1 Sungguminasa. Pengaruh tersebut dilihat dari nilai hasil uji- $f$ yang terdapat pada tabel 4.11 dengan nilai $\mathrm{F}_{\text {hitung }}>\mathrm{F}_{\text {tabel }}(468,325>3,14)$ dan nilai signifikansi yang diperoleh $0,000<0,05$. Ini berarti bahwa uji regresi linear berganda telah terpenuhi. Adapun persamaan regresi yang diperoleh yaitu: $\mathrm{Y}=8,303+0,282 \mathrm{X}_{1}+0,617 \mathrm{X}_{2}$.

Hasil penelitian ini sejalan dengan pendapat Smith (Kharisma, dkk, 2019: 22) yang menyatakan bahwa "kecerdasan interpersonal merupakan kemampuan dalam mengerti harapan, maksud serta motivasi orang lain”. Siswa yang memiliki kecerdasan interpersonal akan lebih mengutamakan kolaborasi dan kerja sama. Hasil penelitian ini juga sejalan dengan Pianyta, A (2016: 22) yang mendefinisikan "task commitment sebagai motivasi dan faktor pemicu dalam diri seseorang yang mendorong orang untuk tekun dan ulet dalam mengerjakan tugas yang sudah menjadi tanggung jawabnya, meskipun menghadapi berbagai macam halangan".Oleh sebab itu, kecerdasan interpersonal dan task commitment sangatlah berpengaruh terhadap prestasi belajar matematika.Kedua variabel tersebut dapat dikatakan bagian dari faktor yang dapat mempengaruhi prestasi belajar siswa.Apabila kecerdasan interpersonal siswa baik, dimana kecerdasan tersebut dapat dikatakan sebagai kemampuan sosialnya dan diiringi dengan task commitment yang baik pula maka secara bersama-sama dapat menjadikan prestasi belajar matematika jauh lebih baik.

3. Pengaruh Kecerdasan Interpersonal terhadap Prestasi Belajar Matematika $\left(\mathrm{X}_{1}-\mathrm{Y}\right)$

Pada hasil uji analisis untuk tiap variabel bebas diperoleh nilai $t_{\text {hitung }}>\mathrm{t}_{\text {tabel }}$ $(5,497>1,9971)$ dan nilai signifikansi sebesar $0,000<0,05$. Ini berarti bahwa kecerdasan interpersonal memiliki pengaruh terhadap prestasi belajar matematika siswa kelas VIII SMP Negeri 1 Sungguminasa.

Sejalan dengan penelitian yang dilakukan oleh Nofyanti Dewi, dkk tahun 2020 yang berjudul "Pengaruh Kecerdasan Interpersonal Dan Kebiasaan Belajar Terhadap Prestasi Belajar Matematika Siswa Kelas VII”. Hasil Penelitian menunjukkan bahwa terdapat pengaruh kecerdasan interpersonal terhadap prestasi belajar matematika, hal ini dapat dilihat dari perolehan hasil uji regresi diperoleh nilai signifikannya sebesar 0,041<0,05.

4. Pengaruh Task Commitment terhadap Prestasi Belajar Matematika $\left(\mathrm{X}_{2}-\mathrm{Y}\right)$

Pada hasil uji analisis untuk tiap variabel bebas diperoleh nilai nilai $t_{\text {hitung }}>\mathrm{t}_{\text {tabel }}$ $(10,433>1,9971)$ dan nilai signifikansi sebesar $0,000<0,05$. Ini berarti bahwa task commitment memiliki pengaruh terhadap prestasi belajar matematika siswa kelas VIII SMP Negeri 1 Sungguminasa.

Sejalan dengan penelitian yang dilakukan oleh Ulfah, Maria tahun 2018 yang berjudul 
"Pengaruh Task Commitment Terhadap Prestasi Belajar Matematika Siswa Kelas VIII Di MTs Raudhatusysyubban Sungai Lulut Tahun Pelajaran 2017/2018”. Berdasarkan pengujian hipotesis diperoleh thitung sebesar $4,503(4,503>1,697)$ dengan nilai signifikan $0,016(0,016<0,05)$, hal ini menunjukkan bahwa terdapat pengaruh yang signifikan antara task commitment terhadap prestasi belajar matematika

\section{Kesimpulan}

Berlandaskan dari beberapa hasil dalam penelitia ini yang telah sebelumnya telah dibahas pada bab IV, penelitin memberi simpulan secara rinci, yakni :

a. Gambaran umum tiap variabel dalam penelitian ini menunjukkan bahwa kecerdasan interpersonal dan task commitment siswa kelas VIII SMP Negeri 1 Sungguminasa telah diketahui memenuhi kategori sangat baik dengan persentase sebesar $48 \%$ dan $33 \%$ untuk variabel kecerdasan interpersonal dan variabel task commitment. Sedangkan pada variabel prestasi belajar matematika memenuhi kategori baik dengan persentase sebesar $39 \%$.

b. Terdapat pengaruh kecerdasan interpersonal dan task commitment secara bersama-sama terhadap prestasi belajar matematika siswa kelas VIII SMP Negeri 1 Sungguminasa dengan memperoleh nilai signifikansi yakni $0,000<0,05(0,05$ adalah nilai taraf signifikan $\alpha$ ) dan $F_{\text {hitung }}>F_{\text {tabel }}$ yakni 468,325 $>3,14$.

c. Terdapat pengaruh kecerdasan interpersonal terhadap prestasi belajar matematika siswa kelas VIII SMP Negeri 1 Sungguminasa dengan memperoleh nilai signifikansi yakni $0,000<0,05(0,05$ adalah nilai taraf signifikan $\alpha)$ dan $t_{\text {hitung }}>t_{\text {tabel }}$ yakni 5,497 $>$ 1,9971 .

d. Terdapat pengaruhtask commitment terhadap prestasi belajar matematika siswa kelas VIII SMP Negeri 1 Sungguminasa dengan memperoleh nilai signifikansi yakni 0,000< $0,05(0,05$ adalah nilai taraf signifikan $\alpha)$ dan $t_{\text {hitung }}>t_{\text {tabel }}$ yakni 10,433 $>1,9971$.

\section{DAFTAR PUSTAKA}

Aunurrahman. 2011. Belajar Dan Pembelajaran. Bandung: Alfabeta.

Kharisma, D. dkk. 2019. "Pengaruh Kecerdasan Interpersonal, Regulasi Diri, dan Kemampuan Berpikir Logis Terhadap Prestasi Belajar Matematika Siswa Kelas XII SMA Negeri 2 Sengkang". Jurnal Nalar Pendidikan, 7(1):21-27.

Lwin, M. dkk. 2008. Cara Mengembangkan Berbagai Komponen Kecerdasan. Jakarta: Indeks. 
Pianyta, A. 2016. "Pengaruh Kedisiplinan Dan Task Commitment Terhadap Prestasi Belajar Matematika". Jurnal JKPM, 2(1):80-92.

Rohman, H.F. 2015. "Pengaruh Kecerdasan Interpersonal Dan Kebiasaan Belajar Terhadap Prestasi Belajar Matematika Siswa Kelas VII". Jurnal Delta, 3(2):8-16.

Sardiman, AM. 2014. Interaksi Dan Motivasi Belajar. Jakarta: Rajawali Press.

Slameto. 2010. Belajar Dan Faktor-Faktor Yang Mempengaruhi. Jakarta: Rineka Cipta.

Suhendri, H. 2011. "Pengaruh Kecerdasan Matematis-Logis Dan Kemandirian Belajar Terhadap Hasil Belajar Matematika" Formatif: Jurnal Ilmiah Pendidikan MIPA, 1(1):29_ 39.

Ulfah, M. 2018. Pengaruh Task Commitment Terhadap Prestasi Belajar Matematika Siswa Kelas VIII Di MTs Raudhatusysyubban Sungai Lulut Tahun Pelajaran 2017/2018. Skripsi. UIN Antasari Banjarmasin. 